\title{
Comment on: oral cancer in young adults
}

$\mathrm{M}$ alignancy of the mouth in childhood and early adulthood is uncommon. Oral cancers in childhood often reflect congenital disease and/or represent malignancies of developing tissues (eg rhabdomyosarcomas, acute leukaemias). In early adulthood, oral tumours may reflect infection such as Epstein-Barr virus or human herpes virus- 8 together with congenital or acquired immunodeficiency. The present report by Oliver and co-workers highlights knowledge that while accounting for less than $4 \%$ of all oral malignancies, in developed populations, ${ }^{1,2}$ squamous cell carcinoma, especially of the tongue, is a common head and neck malignancy in young adults, ${ }^{3,4}$ has the same clinical features as similar disease in older patients, and has a variable clinical outcome. ${ }^{5-9}$

Knowledge of the aetiology, clinical behaviour and effective management of oral SCC in young adults is limited and sometimes contradictory. Tobacco and alcohol are not always implicated in the aetiology of oral SCC of young adults, ${ }^{8,10}$ and the pathogenic role of other recreational drugs is unclear. ${ }^{11,12}$ A genetic basis for oral SCC in young adults has been proposed, ${ }^{13,17}$ but any causative role for infective agents such as Epstein-Barr virus (EBV), ${ }^{18}$ human papillomavirus (HPV), ${ }^{19}$ hepatitis $C,{ }^{20}$ or hepatitis $\mathrm{G}$ viruses, ${ }^{21}$ and human immunodeficiency virus (HIV), ${ }^{22}$ remains to be established.

There is a need to establish the precise oncogenic mechanisms that underly such disease, as they may be different to those of oral SCC of older individuals. ${ }^{23}$ Paradoxically of course, an immediate stumbling block to such research is the low number of affected patients, hence there would be a need for collaborative multi-centre studies, as in London.

The low incidence of oral SCC and other malignant or potentially malignant disease in young adults indicates strongly that specific screening programmes would neither be realistic nor cost effective. Dental health care staff do, however, have an important role in the care of young adults with possible malignant disease. The social history of all patients should be carefully reviewed, and appropriate preventative advice provided regarding tobacco and alcohol habits. In view of the potential link between general oral health and risk of malignancy, ${ }^{24}$ all patients should be advised to maintain a high standard of oral hygiene. The clinical features are not notably influenced by the age of the patient, ${ }^{25}$ hence the effective and timely referral by a primary healthcare provider to a specialist centre of any individual with a solitary white and/or red oral mucosal lesion, or an area of ulceration unlikely to be caused by local trauma is important. The potential dysplastic nature of any suspicious lesion may be accurately assessed by newer/cytopathological techniques as currently available in the US and shortly in the UK. ${ }^{26}$ Delay in referral of individuals (regardless of patient age) ${ }^{27}$ with a potentially malignant lesion can limit potential treatment options, and ultimately adversely affect prognosis.

\section{S. Porter, A. Waugh}

Department of Oral Medicine, Eastman Dental Institute for Oral Health Care Sciences, University College London, University of London

1 Cusumano R J, Persky MS. Squamous cell carcinoma of the oral cavity and oropharynx in young adults. Head Neck Surg 1988; 10; 229234.

2 Tsukuda M, Ooishi K, Mochimatsu I, Sato H. Head and neck carcinomas in patients under the age of forty years. Jpn J Cancer Res 1993; 84: 748-752.

3 Randall C J, Shaw H J. Malignant tumours of the tongue in young adults - experience of a secondary referral centre. J Laryngol \& Otol 1986; 100: 1295-1298.

4 Lund V J, Howard D J. Head and neck cancer in the young: A prognostic conundrum? J Laryngol \& Otol 1990; 104: 544-548.

5 Clarke R W, Stell P M. Squamous carcinoma of the head and neck in the young adult. Clin Otolaryngol 1992; 17: 18-23.

6 Von Doesten P G, Cruz R M, Rasgon B M, Quensenberry C P, Hilsinger R L. Relation between age and head and neck cancer recurrence after surgery: A multivariate analysis. Otolaryngol Head Neck Surg 1995; 113 : 197-203.

7 Agula S, Grenman R, Laippala P, Syrjanen S. Cancer of the tongue in patients younger than 40 years. A distinct entity? Arch Otolaryngol Head Neck Surg 1996; 122: 1313-1319.

8 Martin-Granizo R, Rodriguez-Campo F, Naval L, Diaz Gonzalez F J. Squamous cell carcinoma of the oral cavity in patients younger than 40 years. Otolaryngol Head Neck Surg 1997; 117: 268-75.

9 Verschuur H P, Irish J C, O’Sullivan B, Goh C, Gullane P J, Pintilie M. A matched control study of treatment outcome in young patients with squamous cell carcinoma of the head and neck. Laryngoscope 1999; 109: 249-258.

10 Schantz S P, Byers R M, Goepfert H. Tobacco and cancer of the tongue in young adults. JAMA 1988; 259:letter to editor.

11 Donald P J. Marijuana smoking - possible cause of head and neck carcinoma in young patients. Otolaryngol Head Neck Surg 1986; 94: 517.
12 Donald P J. Advanced malignancy in the young marijuana smoker. In Friedman et al (eds) Drugs of Abuse, Immunity and Immunodeficiency. New York: Plenum Press, 1991.

13 Copper M P, Jovanovic A, Nauta J J et al. Role of genetic factors in the etiology of squamous cell carcinoma of the head and neck. Arch Otolaryngol Head Neck Surg 1995; 121 : 157-60.

14 Foulkes W D, Brunet J S, Sieh W, Black M J, Shenouda G, Narod S A. Familial risks of squamous cell carcinoma of the head and neck: retrospective case-control study. $\mathrm{Br} \mathrm{Med} \mathrm{J} \mathrm{1996;}$ 313: 716-721.

15 Foulkes W D, Brunet J S, Kowalski L P, Narod S A, Franco E L. Family history of cancer is a risk factor for squamous cell carcinoma of the head and neck in Brazil: a case-control study. Int J Cancer 1995; 63: 769-773.

16 Goldstein A M, Blot W J, Greenberg R S et al. Familial risk in oral and pharyngeal cancer. Eur J Cancer, Oral Oncol 1994; 30B: 319-322.

17 Mork J, Moller B, Glattre E. Familial risk in head and neck squamous cell carcinoma diagnosed before the age of 45: a populationbased study. Oral Oncol 1999; 35: 360-367.

18 Van Heerden W F P, Van Rensburg E J, Engelbrecht S, Raubenheimer E J. Prevalence of EBV in oral squamous cell carcinomas in young patients. Anticancer Res 1995; 15: 2335-2340.

19 Maden C, Beckmann A M, Thomas D B et al. Human papillomaviruses, herpes simplex viruses, and the risk of oral cancer in men. Am J Epidemiol 19992; 135: 1093-1102.

20 Nagao Y, Sata M, Fukuizumi K, Harada H, Kameyama T. Oral cancer and hepatitis $\mathrm{C}$ virus (HCV): can $\mathrm{HCV}$ alone cause oral cancer? A case report. Kurume Med J 1996; 43: 97-100.

21 Nagao Y, Sata M, Noguchi S et al. GB virus infection in patients with oral cancer and oral lichen planus. J Oral Pathol Med 1997; 26: 138-141.

22 Flaitz C M, Nichols C M, Adler-Storthz K, Hicks M J. Intraoral squamous cell carcinoma in human immunodeficiency virus infection. A clinicopathologic study. Oral Surg Oral Med Oral Pathol Oral Radiol Endod 1995; 80: 55-62.

23 Sorensen D M, Lewark T M, Haney J L, Meyers A D, Krause G, Franklin W A. Absence of p53 mutations in squamous carcinomas of the tongue in non-smoking and non-drinking patients younger than 40 years. Arch Otolaryngol Head Neck Surg 1998; 123: 503-506.

24 Velly A M, Franco E L, Schlecht N, Pintos J, Kowalski L P, Oliveira B V, Curado M P. Relationship between dental factors and risk of upper aerodigestive tract cancer. Oral Oncol 1998; 34: 284-291

25 Hart A K E, Karakla D W, Pitman KT, Adams J F. Oral and oropharyngeal squamous cell carcinoma in young adults: A report on 13 cases and review of the literature. Otolaryngol Head Neck Surg 1999; 120: 828-833.

26 Sciubba J. Improving detection of precancerous and cancerous oral lesions. JADA 1999; 130: 1445-1457.

27 Allison P, Locker D, Feine J S. The role of diagnostic delays in the prognosis of oral cancer: a review of the literature. Oral Oncol 1998; 34: 161-170. 